\title{
CARPOSEMINAL BIOMETRY AND GERMINATION OF Cabralea canjerana (Vell.) Mart.
}

\author{
Helena Cristina Rickli-Horst ${ }^{1 *}$; Manoela Mendes Duarte²; Cacilda João Chirinzane²; \\ Antonio Carlos Nogueira ${ }^{2}$ \\ ${ }^{1 *}$ Federal University of Paraná, Graduate Program in Plant Production, Curitiba, Paraná, Brazil - helenarickli@gmail.com \\ ${ }^{2}$ Federal University of Paraná, Graduate Program in Forestry, Curitiba, Paraná, Brazil - manu-florestal@ hotmail.com; \\ cacildachirinzane@gmail.com; acnogueira.ufpr@gmail.com
}

Received for publication: 25/07/2017 - Accepted for publication: 03/11/2017

\begin{abstract}
Cabralea canjerana is a species that has ecological and economic importance for the Southern Brazil. This study aimed to characterize the biometry of fruits and seeds as well as the $C$. canjerana germinative process submitted to different substrates and temperatures. The biometric characteristics of fruits and seeds were analyzed with the aid of digital caliper. In the germination test, the substrates blotting paper, sand and vermiculite, and the temperatures of 20,25 and $30{ }^{\circ} \mathrm{C}$ were used. The germination percentage, mean germination rate (MGR), mean germination time (MGT), synchronization index (SI), fresh mass (FS) and dry mass (DM) of seedlings were assessed. The highest germination percentages occurred for vermiculite at three temperatures, blotting paper at $25^{\circ} \mathrm{C}$ and sand at 20 and $30^{\circ} \mathrm{C}$. There was seedling formation in all treatments. The use of the sand substrate and the temperatures of 25 and $30^{\circ} \mathrm{C}$ provided lower mean values of MGT and SI and higher mean values of MGR. The highest DM occurred with sand at the temperature of $20^{\circ} \mathrm{C}$. The biometric characteristics of fruits and seeds varied. We recommend the use of vermiculite at temperatures of 20,25 and $30^{\circ} \mathrm{C}$, blotting paper at $25^{\circ} \mathrm{C}$ and sand at 20 and $30{ }^{\circ} \mathrm{C}$ for germination tests. Keywords: Meliaceae; native species; germination potential; temperature, substrate.
\end{abstract}

\section{Resumo:}

Biometria carpo seminal e germinação de Cabralea canjerana (Vell.) Mart. Cabralea canjerana é uma espécie que possui importância ecológica e econômica para o Sul do Brasil. Este estudo objetivou caracterizar a biometria de frutos e sementes, assim como o processo germinativo de $C$. canjerana submetido a diferentes substratos e temperaturas. Analisaram-se as características biométricas de frutos e sementes com auxílio de paquímetro digital. No teste de germinação, foram utilizados os substratos papel mata-borrão, areia e vermiculita e as temperaturas de 20,25 e $30{ }^{\circ} \mathrm{C}$, avaliando-se a porcentagem de germinação, velocidade média de germinação (VMG), tempo médio de germinação (TMG), índice de sincronização (I), massa fresca (MF) e massa seca (MS) de plântulas. As maiores porcentagens de germinação ocorreram com vermiculita nas três temperaturas, papel mata-borrão a $25{ }^{\circ} \mathrm{C}$ e areia a 20 e $30{ }^{\circ} \mathrm{C}$. Houve formação de plântulas em todos os tratamentos. $\mathrm{O}$ uso do substrato areia e das temperaturas de 25 e $30^{\circ} \mathrm{C}$ proporcionou menores médias de TMG e I e maiores médias de VMG. A maior MS ocorreu utilizando-se areia sob temperatura de $20^{\circ} \mathrm{C}$. Ocorreu variação das características biométricas de frutos e sementes. Recomenda-se a utilização de vermiculita nas temperaturas de 20,25 e $30^{\circ} \mathrm{C}$, papel mata-borrão a $25^{\circ} \mathrm{C}$ e areia a 20 e $30^{\circ} \mathrm{C}$ para testes de germinação.

Palavras-chave: Meliaceae; espécie nativa; potencial germinativo; temperatura; substrato.

\section{INTRODUCTION}

The biometric studies of fruits and seeds are an indispensable source of information and help determine characteristics of dispersion and establishment of seedlings in native forests. In addition, they subsidize the differentiation of species of the same genus; thus, they help to identify the genetic variability within population of the same species and in the relationships between such variability and environmental factors. Therefore, they can be used in different research, including genetic improvement programs (SANTOS et al., 2009; GONÇALVES et al., 2013). Despite this importance, there is a lack of research that contemplates these aspects, both for native and exotic species, which complicates the conduction of studies focusing on natural regeneration, silvicultural activities and preservation of endangered species.

In addition to the biometric aspects, the germination potential is one of the main characteristics of interest for the study of forest seeds; it is assessed, mainly, from germination tests carried out in the laboratory. In general, the seeds present a variable performance regarding germination at different temperatures and FLORESTA, Curitiba, PR, v. 47, n. 4, p. 391 - 396, out/dez. 2017.

Rickli-Horst, H. C. et al.

ISSN eletrônico 1982-4688

DOI: $10.5380 /$ rf.v47i4.54128 
substrates. Thus, knowledge of the influence and interactions of these factors for each species is of fundamental importance (MONDO et al., 2008).

Therefore, substrate and temperature are two of the most important laboratory factors that influence the germination of the seeds (BASSACO et al., 2014). The substrate may influence the germination due to its water holding capacity, structure and aeration, and may favor or impair the germination process (GUEDES et al., 2010). The most employed substrates for germination tests are paper and sand (BRASIL, 2009) as well as vermiculite, which has been used for native forest species with good results (LIMA JUNIOR, 2010). Temperature has a strong influence on the germination speed and uniformity, and is related to biochemical processes (CARVALHO; NAKAGAWA, 2012). Seeds exhibit variable behavior at different temperatures, and there is no determination of an optimum value for all species. However, the range of 20 to $30{ }^{\circ} \mathrm{C}$ shows to be adequate for the germination of a large number of forest species (MARCOS FILHO, 2005).

Cabralea canjerana (Vell.) Mart. (Meliaceae), popularly known as canjerana, is a species of ecological importance and wide natural occurrence in Brazil. The species is present in secondary forest and, mainly, in capoeirões, characteristic of the Atlantic Forest (CARVALHO, 2003; STEFANO et al., 2015). The species is also adaptable to floods, and recommended for the recovery of ciliary forests (DURIGAN; NOGUEIRA, 1990). In addition, its wood presents great quality and satisfactory resistance to the attack of xylophagous organisms (CARVALHO, 2003). Its seeds are consumed by several species of birds because they are surrounded by aril, which makes $C$. canjerana indispensable in the composition of heterogeneous reforestation of areas destined for conservation (CARVALHO, 2003). Regarding silviculture, its seeds lose their viability quickly, and storage is not being recommended due to their recalcitrant characteristics (CARVALHO, 2003).

Since it is a native species of ecological and economic importance, this study aimed to characterize the carposeminal biometry and assess the germinative behavior of seeds of $C$. canjerana submitted to different substrates and temperatures.

\section{MATERIAL AND METHODS}

The research was conducted in the Laboratory of Forest Seeds of the Federal University of Paraná (Laboratório de Sementes Florestais da Universidade Federal do Paraná (UFPR)) in Curitiba, PR. Material was collected from five mother trees in November 2013 in Colombo, PR. The fruits were collected directly from the crown of the trees when they were reddish.

For induction of dehiscence, the fruits were kept in closed polypropylene bags at room temperature for 48 hours. Then, the seeds were washed for aryl extraction and exposed to a ventilated area for 72 hours. After this process, the manual selection was performed to remove inert material in order to obtain a batch of pure seeds of C. canjerana.

For the study of biometric characteristics, 50 fruits and seeds were taken from the batch at random. For the characterization of the fruits, which were analyzed when closed, the following aspects were measured: length, taken from the apex to the base; diameter, taken in the median line of the fruit; mean number of locules per fruit; mean number of seeds per fruit; and mean number of seeds per locule. The length and diameter of the seeds were determined. In relation to the measurements, a digital caliper with accuracy of $0.01 \mathrm{~mm}$ was used.

The moisture content of the seeds by the oven method at $105^{\circ} \mathrm{C} \pm 3{ }^{\circ} \mathrm{C}$ for 24 hours and the weight of 1000 seeds were determined for the physical characterization of the batch. Eight repetitions of 100 pure seeds were used and weighed in an analytical scale with precision of $0.0001 \mathrm{~g}$ according to the methodologies described in the Rules for Seed Testing - RAS (BRASIL, 2009). From the determination of the weight of 1000 seeds, the number of seeds per kilo was calculated. The experiment was conducted in a completely randomized design to assess the effect of temperature and substrate on the germination of $C$. canjerana seeds. Thus, the $3 \times 3$ factorial arrangement, organized in three temperatures $\left(20,25\right.$ and $\left.30{ }^{\circ} \mathrm{C}\right)$ and three substrates (sand, vermiculite, and blotting paper) was adopted; ten repetitions of 20 seeds per experimental unit, packed in gerbox boxes and allocated in germinators of the Mangelsdorf type under constant white light were performed.

The substrate sand was uniformed in a mesh sieve of $0.8 \mathrm{~mm}$, washed and oven sterilized at $200{ }^{\circ} \mathrm{C}$ for two hours. $100 \mathrm{~g}$ for each gerbox were used and moistened with distilled water (50\% of holding capacity). For vermiculite, $20 \mathrm{~g}$ were used in each gerbox, added with $70 \mathrm{~mL}$ of water. For the substrate blotting paper, a sheet of paper moistened with 2.5 times the weight of the substrate was used. During the conduction of the experiment, water was replaced whenever necessary.

The assessments occurred daily, and were initiated on the first day after the experiment was set up and continued until germination had stabilized for three consecutive days. The adopted germination criteria were: protrusion of the primary root with approximately $5 \mathrm{~mm}$ of length and formation of normal seedlings when they presented opening of the cotyledons. The following measures were calculated: germination percentage $(\mathrm{G})$; mean 
germination time (MGT) according to Labouriau (1983); mean germination rate (MGR) and synchronization index (SI) according to Labouriau and Agudo (1987); percentage of seedlings (P); fresh mass (FM) and dry mass (DM) of the seedlings. For the calculation of the fresh mass of seedlings, ten seedlings of each treatment were weighed in an analytical balance with precision of $0.0001 \mathrm{~g}$. Afterwards, they were packed in paper bags and taken to the forced circulation oven at $60^{\circ} \mathrm{C}$ for 72 hours for weighing and obtaining the dry mass.

The means of the treatments were analyzed by Bartlett's test regarding the homogeneity of variances. Those that did not present homogeneity were transformed by $\sqrt{ } \mathrm{x}$. Subsequently, they were submitted to analysis of variance, and those that presented significant differences by the F-test had their means compared by the Tukey test at the level of probability of $5 \%$.

\section{RESULTS}

The batch of $C$. canjerana seeds showed a moisture content of $51.6 \%$ after collection and processing. In addition to it, we observed that the weight of 1000 seeds equals to $466,96 \mathrm{~g}(\mathrm{CV}=4.29 \%)$ and the number of seeds per kilo to 2.141 (Table 1). With regards to the biometry, the fruits showed the mean length of $33,2 \mathrm{~mm}$ and mean diameter of $35.1 \mathrm{~mm}$. The presence of 5 to 6 locules per fruit, 5 to 10 seeds per fruit and 1 to 2 seeds per locule were observed. The seeds had mean size of $10.4 \mathrm{~mm}$ in length and $8.6 \mathrm{~mm}$ in diameter (Table 1).

Table 1. Means of fruit length and diameter, number of locules per fruit, number of seeds per fruit, number of seeds per locule, length and diameter of $C$. canjerana seeds.

Tabela 1. Médias de comprimento e diâmetro do fruto, número de lóculos por fruto, número de sementes por fruto, número de sementes por lóculo, comprimento e diâmetro de sementes de C. canjerana.

\begin{tabular}{llll}
\hline Determinations & Minimum & Medium & Maximum \\
\hline Length of fruit $(\mathrm{mm})$ & 26.9 & $33.2 \pm 2.34$ & 37.1 \\
Diameter of fruit $(\mathrm{mm})$ & 27.9 & $35.1 \pm 2.47$ & 38.6 \\
$\mathrm{~N}^{\circ}$ of locules/fruit & 5 & $5.0 \pm 0.20$ & 6 \\
$\mathrm{~N}^{\text {o } \text { of seeds/fruit }}$ & 5 & $8.6 \pm 1.16$ & 10 \\
$\mathrm{~N}^{\circ}$ of seed/locule & 1 & $1.7 \pm 0.24$ & 2 \\
Length of seed $(\mathrm{mm})$ & 8.6 & $10.4 \pm 0.85$ & 12.2 \\
Diameter of seed (mm) & 7.2 & $8.6 \pm 0.76$ & 9.9 \\
Weight of a thousand seeds $(\mathrm{g})$ & & $466.96 \pm 2.00$ & \\
Number of seeds/Kg & & 2,141 & \\
Moisture content & & $51.6 \%$ & \\
\hline
\end{tabular}

The variables germination percentage and seedlings percentage showed interaction among the temperatures and substrates, which demonstrated that they are dependent factors. However, for the mean germination time (MGT), mean germination rate (MGR), synchronization index (SI), fresh mass (FM) and dry mass (DM) of seedlings, there was no interaction among the studied factors. The means of the analyzed variables are presented in Tables 2 and 3.

For the variable of germination percentage, the vermiculite substrate showed the highest means at all evaluated temperatures (Table 2). As for seedlings formation, the vermiculite substrate at the temperature of $25{ }^{\circ} \mathrm{C}$ presented the highest mean percentage of seedlings $(98 \%)$, differing from the sand substrate at the same temperature, and vermiculite at the temperature of $20^{\circ} \mathrm{C}$ (Table 2).

The temperatures of 25 and $30{ }^{\circ} \mathrm{C}$ showed higher mean values for MGR and lower mean values for MGT (Table 3), characterizing these treatments as of more homogeneous germination compared to other treatments. The same occurred for the sand substrate. Regarding the synchronization index, the temperatures of 25 and $30{ }^{\circ} \mathrm{C}$ and the sand substrate showed higher synchrony in the germination process of $C$. canjerana seeds (Table 3). When analyzing the results of fresh mass of seedlings, it is possible to observe that the temperature of $25{ }^{\circ} \mathrm{C}$ provided the highest mean mass, with $11.5 \mathrm{~g}$, differing statistically from the others. With regards to the substrates, the use of blotting paper reduced significantly the mean fresh mass of $C$. canjerana seedlings $(9,9 \mathrm{~g})$. It is also possible to verify that $C$. canjerana seedlings showed higher mean dry mass when the seeds were submitted to the temperature of $20^{\circ} \mathrm{C}(2.4 \mathrm{~g})$ and the sand and vermiculite substrates $(2.3$ and $2.2 \mathrm{~g}$, respectively), showing to be statistically superior to the other treatments. 
Table 2. Percentage of germination and percentage of seedlings formed of $C$. canjerana submitted to different temperatures and substrates.

Tabela 2. Porcentagem de germinação e porcentagem de plântulas formadas de C. canjerana submetidas a diferentes temperaturas e substratos.

\begin{tabular}{lrrll}
\hline & & \multicolumn{3}{c}{ Substrate } \\
\cline { 2 - 4 } Gemperature & Blotting paper & Sand & Vermiculite \\
\hline \multirow{2}{*}{ Germination } & $20^{\circ} \mathrm{C}$ & $90 \mathrm{bB}$ & $92 \mathrm{abAB}$ & $98 \mathrm{aA}$ \\
$(\boldsymbol{\%})$ & $25^{\circ} \mathrm{C}$ & $96 \mathrm{aA}$ & $87 \mathrm{bB}$ & $99 \mathrm{aA}$ \\
& $30^{\circ} \mathrm{C}$ & $89 \mathrm{bB}$ & $94 \mathrm{aAB}$ & $98 \mathrm{aA}$ \\
\multirow{2}{*}{ Seedlings } & $20^{\circ} \mathrm{C}$ & $90 \mathrm{aA}$ & $92 \mathrm{aA}$ & $89 \mathrm{bA}$ \\
$(\boldsymbol{\%})$ & $25^{\circ} \mathrm{C}$ & $96 \mathrm{aA}$ & $87 \mathrm{aB}$ & $98 \mathrm{aA}$ \\
& $30^{\circ} \mathrm{C}$ & $89 \mathrm{aA}$ & $93 \mathrm{aA}$ & $96 \mathrm{abA}$ \\
\hline
\end{tabular}

Means followed by the same letter, uppercase for the rows and lowercase for the columns, do not differ from each other at the 5\% probability level by the Tukey Test.

Table 3. Mean germination time (MGT), mean germination rate (MGR), synchronization index (SI), seedling fresh mass (FM) and seedling dry mass (DM) of C. canjerana submitted to different temperatures and substrates.

Tabela 3. Tempo médio de germinação (TMG), velocidade média de germinação (VMG), índice de sincronização (I), massa fresca de plântulas (MF) e massa seca de plântulas (MS) de C. canjerana submetidas a diferentes temperaturas e substratos.

\begin{tabular}{llllll}
\hline Temperature & MGT & MGR & SI & FM $(\mathbf{g})$ & DM $(\mathbf{g})$ \\
\hline $20^{\circ} \mathrm{C}$ & $12.4 \mathrm{~b}$ & $0.0845 \mathrm{~b}$ & $2.84 \mathrm{~b}$ & $10.2 \mathrm{~b}$ & $2.4 \mathrm{a}$ \\
$25{ }^{\circ} \mathrm{C}$ & 7.8 & $0.1319 \mathrm{a}$ & $2.12 \mathrm{a}$ & $11.5 \mathrm{a}$ & $2.2 \mathrm{~b}$ \\
$30^{\circ} \mathrm{C}$ & $8.2 \mathrm{a}$ & $0.1284 \mathrm{a}$ & $2.34 \mathrm{a}$ & $9.7 \mathrm{~b}$ & $2.0 \mathrm{c}$ \\
\hline Substrates & MGT & MGR & SI & FM $(\mathbf{g})$ & DM $(\mathbf{g})$ \\
\hline Blotting paper & $11.8 \mathrm{c}$ & $0.0916 \mathrm{c}$ & $2.73 \mathrm{c}$ & $9.9 \mathrm{~b}$ & $2.1 \mathrm{~b}$ \\
Sand & 7.8 & $0.1352 \mathrm{a}$ & $2.13 \mathrm{a}$ & $10.5 \mathrm{a}$ & $2.3 \mathrm{a}$ \\
Vermiculite & $8.8 \mathrm{~b}$ & $0.1180 \mathrm{~b}$ & $2.44 \mathrm{~b}$ & $10.9 \mathrm{a}$ & $2.2 \mathrm{ab}$ \\
\hline
\end{tabular}

Means followed by the same lowercase letter in the column do not differ at the 5\% probability level by the Tukey Test.

\section{DISCUSSION}

The high moisture content presented by $C$. canjerana fresh seeds is characterizes recalcitrant species, i.e., seeds that do not tolerate the reduction of their water content, losing viability quickly when stored at low temperatures, as already mentioned by Carvalho (2003). The observed values for fruits and seeds biometry fit in the descriptions made by Carvalho (2003) and Felippi et al. (2015b). In addition, for the physical features, Aimi et al. (2016) found, for the same species, values close to those of this study and higher than those mentioned by Carvalho (2003), which mentions the presence of 1,200 seeds/Kg. Commonly, differences are observed in the results obtained in studies with the same species in the literature. Aimi et al. (2016) highlight that the observed variations can be associated to the location, harvesting time, and maturity stages of the fruits. The number of seeds per kilogram, weight of 1000 seeds and moisture content are specific parameters of each batch, indicating a trend only for the studied species.

This study verified that the germination of $C$. canjerana occurred uniformly and with high percentage in all tested substrates and temperatures, as well as the formation of seedlings in all treatments. On the one hand, the overall mean of germination percentage of this study (94\%) was similar to the germination mentioned by Carvalho (2003) (93\%). On the other hand, when evaluating the germination of different matrices of $C$. canjerana with vermiculite substrate at $25^{\circ} \mathrm{C}$, Felippi et al. (2015a) obtained lower and non-uniform results, ranging from 22 to $86 \%$ of germination, according to each mother plant. In face of the results, the same authors highlight that the low quality of the seeds may be associated to the physiological maturity of each mother plant. This is an important factor to be considered when aiming at the seeds collection. They also highlight that aspects such as the color of the fruits, when used alone, are insufficient to determine the appropriate moment for the collect of $C$. canjerana seeds.

The use of vermiculite as a substrate for germination tests in the laboratory has shown good results and has been recommended for several forest species, as it is possible to verify in the studies developed for Myracrodruon urundeuva Allemão (PACHECO et al., 2006), Amburana cearensis (Allemão) A. C. Smith (GUEDES et al., 2010), Caesalpinia pyramidalis Tul. (LIMA et al., 2011) and Hymenaea courbaril L. 
(DUARTE et al., 2016). The Instructions for Seed Testing of Forest Species (BRAZIL, 2013) indicate the use of the vermiculite substrate (vermiculite method) together with the temperatures of 25 and $30{ }^{\circ} \mathrm{C}$ for the species of C. canjerana, and the use of the vermiculite method in this study did not cause damages to the germination. Thus, it is possible to recommend the vermiculite combined with all the tested temperatures, as well as of the blotting paper at $25^{\circ} \mathrm{C}$ and the sand at 20 and $30{ }^{\circ} \mathrm{C}$ for germination tests of this species (Table 2).

Regarding temperatures, we could observe high germination rates of $C$. canjerana at all tested temperatures (Table 2), demonstrating the plasticity of the studied species. From the ecological point of view, this is an important characteristic of adaptation of species, which allows the seeds to germinate easily in different environments within a forest, demonstrating their plasticity in face of the natural thermal fluctuations of the ecosystems. In view of the variations in the requirements for each species, the need of specific studies is evident in order to determine the optimum temperature, i.e., those that best demonstrate the germination performance, especially, for the natural forest essences. The results presented in this work were higher than those observed by Aimi et al. (2016) for the temperature of $25^{\circ} \mathrm{C}$ with the use of the same substrates. As we already mentioned, this variation can be caused by the physiological quality of the seed, since they are mother plants from another region (Santa Maria, RS) and another collection season (February), unlike the present study.

The variables MGT and MGR are parameters used in germination tests that allow the differentiation of quality and vigor between seed batches. According to Marcos Filho (2005), these results demonstrate that the germination process is accelerated at temperatures and substrate with higher results, presenting greater force, which contributes to the analysis of the germination potential of the species. Another important aspect assessed was the synchronization index, which is not related to the germination percentage, but rather to the way it was distributed over time. Similarly to the mean germination time, the best performance of the synchronization index is associated with the lowest observed values (DUARTE et al., 2015).

According to Nakagawa (1994), more vigorous seeds provide greater transfer of dry mass of the reserve tissue to the embryo during the germination process, resulting in seedlings with greater accumulation of biomass. Guedes et al. (2010) highlight that seedlings with greater mass and greater force might present a better root system. With a larger and more vigorous root system, the seedling will be more effective on capturing water and nutrients. This would result in advantages for its adaptation and survival by the beginning of the germination process.

In addition to the ecological importance of knowing the autoecology and the germinative behavior of the forest species, another important practical and silvicultural aspect is related to the knowledge of the conditions that provide a fast and uniform germination of the seeds, because it will be extremely useful for sowing purposes. The rapid germination and the homogeneous development of seedlings reduce nursery care, since the seedlings develop faster and with better quality, and present better adaptation in the field, where they will be exposed to adverse environmental conditions (PACHECO et al., 2006).

\section{CONCLUSION}

The results obtained with $C$. canjerana seeds enable to conclude that:

- The fruits and seeds show large variation in the biometric characteristics;

- For germination tests in the laboratory, the use of vermiculite at temperatures of 25 and $30{ }^{\circ} \mathrm{C}$, as well as blotting paper at $25^{\circ} \mathrm{C}$ and sand at 20 and $30^{\circ} \mathrm{C}$ is recommended.

\section{REFERENCES}

AIMI, S. C.; ARAUJO, M. M.; MUNIZ, M. F. B.; WALKER, C. Teste de sanidade e germinação em sementes de Cabralea canjerana (Vell.) Mart. Ciência Florestal, v. 26, n. 4, p. 1361-1370, 2016.

BASSACO, M. V. M.; NOGUEIRA, A. C.; COSMO, N. L. Avaliação da germinação em diferentes temperaturas e substratos e morfologia do fruto, semente e plântula de Sebastiania brasiliensis. Revista Floresta, v. 44, n. 3, p. 381-392, 2014.

BRASIL. Ministério da Agricultura, Pecuária e Abastecimento. Regras para análise de sementes. Secretaria de Defesa Agropecuária. Brasília: MAPA/ACS, 2009. 395 p.

BRASIL. Ministério da Agricultura, Pecuária e Abastecimento. Instruções para análises de sementes de espécies florestais. Secretaria de Defesa Agropecuária. Brasília: Mapa/ACS, 2013. 97 p.

CARVALHO, P. E. R. Espécies arbóreas brasileiras. Brasília: Embrapa Informação Tecnológica; Colombo: Embrapa Florestas, 2003. 1039 p. (Coleção espécies arbóreas brasileiras, v. 1). 
CARVALHO, N. M.; NAKAGAWA, J. Sementes: ciência, tecnologia e produção. 5.ed. FUNEP: Jaboticabal, 2012. $590 \mathrm{p}$.

DUARTE, M. M.; MILANI, J. E. F.; BLUM, C. T.; NOGUEIRA, A. C. Germinação e morfologia de sementes e plântulas de Albizia edwallii (Hoehne) Barneby \& J. W. Grimes. Revista Caatinga, v. 28, n. 3, p. 166-173, 2015.

DUARTE, M. M.; PAULA, S. R. P.; FERREIRA, F. R. L.; NOGUEIRA, A. C. Morphological characterization of fruit, seed and seedling and germination of Hymenaea courbaril L. (Fabaceae) ('Jatobá'). Journal of Seed Science, v. 38, n. 3, p. 204-211, 2016.

DURIGAN, G.; NOGUEIRA, J. C. B. Recomposição de matas ciliares: orientações básicas. São Paulo: IF/Série Registros, n. 4, 1990. 14 p.

FELIPPI, M.; ARAÚJO, M. M.; LONGHI, S. J.; LUCIO, A. D. Fenologia reprodutiva e qualidade das sementes de Cabralea canjerana (Vell.) Mart. Ciência Rural, v. 45, n. 12, p. 2137-2142, 2015 a.

FELIPPI, M.; ARAÚJO, M. M.; LONGHI, S. L. Morfologia da flor, fruto, semente, plântula e muda de Cabralea canjerana (Vell.) Mart. Cerne, v. 21, n. 3, p. 387-394, 2015 b.

GONÇALVES, L. G. V.; ANDRADE, F. R.; MARIMON JUNIOR, B. H.; SCHOSSLER, T. R.; LENZA, E.; MARIMON, B. S. Biometria de frutos e sementes de mangaba (Hancronia speciosa Gomes) em vegetação natural na região de Mato Grosso, Brasil. Revista de Ciências Agrárias, v. 26, n. 1, p. 31-40, 2013.

GUEDES, R. S.; ALVES, E. U.; GONÇALVES, E. P.; BRAGA JÚNIOR, J. M.; VIANA, J. S.; COLARES, P. N. Q. Substratos e temperaturas para testes de germinação e vigor de sementes de Amburana cearensis (Allemão) AC Smith. Revista Árvore, v. 34, n. 1, p. 57-64, 2010.

LABOURIAU, L. G. A germinação das sementes. Washington: Secretaria Geral da Organização dos Estados Americanos, 1983. 174 p.

LABOURIAU, L. G.; AGUDO, M. On the physiology of germination in Salvia hispanica L. temperature effects. Anais da Academia Brasileira de Ciências, v. 59, n. 1, p. 37-56, 1987.

LIMA JUNIOR, M. J. V. Manual de procedimentos para análise de sementes florestais. Manaus: UFAM, 2010. $146 \mathrm{p}$.

LIMA, C. R.; PACHECO, M. V.; BRUNO, R. A.; FERRARI, C. S.; BRAGA JÚNIOR, J. M.; BEZERRA, A. K. D. Temperatura e substratos na germinação de sementes de Caesalpinia pyramidalis Tul. Revista Brasileira de Sementes, v. 33, n. 2, p. 16-222, 2011.

MARCOS FILHO, J. Fisiologia de sementes de plantas cultivadas. Piracicaba: FEALQ, 2005. 495 p.

MONDO, V. H. V.; BRANCALION, P. H. S.; CICERO, S. M.; NOVEMBRE, A. D. L. C.; DOURADO-NETO, D. Teste de germinação de sementes de Parapiptadenia rigida (Benth.) Brenan (Fabaceae). Revista Brasileira de Sementes, v. 30, n. 2, p. 177-183, 2008.

NAKAGAWA, J. Testes de vigor baseados na avaliação das plântulas. IN: VIEIRA, R.D.; CARVALHO, N.M. Teste de vigor em sementes. Jaboticabal, FUNEP, 1994. p. 49-85.

PACHECO, M. V.; MATOS, V. P.; FERREIRA, R. L. C.; FELICIANO, A. L. P.; PINTO, K. M. S. Efeito de temperaturas e substratos na germinação de sementes de Myracrodruon urundeuva Fr. All. (Anacardiaceae). Revista Árvore, v. 30, n. 3, p. 359-367, 2006.

SANTOS, F. S.; PAULA, R. C.; SABONARO, D. Z.; VALADARES, J. Biometria e qualidade fisiológica de sementes de diferentes matrizes de Tabebuia chrysotricha (Mart. Ex A. DC.) StandI. Scientia Forestalis, v. 37 , n. 82, p. 163-173, 2009.

STEFANO, M. V.; CALAZANS, L. S. B.; SAKURAGUI, C. M. Meliaceae in Lista de Espécies da Flora do Brasil: Jardim Botânico do Rio de Janeiro, 2015. Disponível em: <http://floradobrasil.jbrj.gov.br/jabot/floradobrasil/FB9988>. Acesso em: 22 jun. 2017. 